\title{
SOCIALIZATION OF HONESTY VALUES THROUGH STORY TELLING FOR CHILDREN IN EARLY AGE IN THE CHILD-FRIENDLY PUBLIC SPACE (RPTRA) JOGLO, WEST JAKARTA
}

\author{
Suraya, Roro Ayu Fatmawati, Dessy Dindasari, Dio Ridho Hutama, \\ Inka Christianti, Venny Irliani Amanah \\ Universitas Mercu Buana Jakarta, Indonesia.
}

\begin{abstract}
This article aims to convey socialization regarding the formation of honesty in early childhood in RPTRA Joglo, West Jakarta. Submission of honesty values through story telling. After carrying out this socialization about honesty, there are many things that can be used as lessons, including: conducting honesty socialization is not easy, especially the target audience of children who do not understand the real problem of honesty. Everything that is good must of course be rushed, including instilling the values of honesty early on in children. If they are used to being honest from childhood, that personality will be carried by them until they become adults. Honesty instilled early on in children is able to encourage them to do even better, so as to create a young generation of quality, superior, and dignified.
\end{abstract}

Keyword: Honesty Values, Story Telling, Early Childhood, Socialization

\section{INTRODUCTION}

Indonesia is one of the countries with the most corruption cases. These corruption cases tend to increase every year. There are several indications that have caused the increase in corruption in Indonesia, including: lack of honesty; high laziness (want something instantaneous); consumptive lifestyle; lack of adherence to religion; and others. https://www.kompasiana.com/www.nabilahfirda.com/54f93e033311f847b4d47/faktor-penyebabkorupsi-menggila-di-indonesia

At present, various indications are found among students. One example of acts of corruption among students is cheating which is the culture of most Indonesian students, from a variety of ways (googling via the internet, chatting with friends, etc.). Another form is leaving absent to colleague during lecture, being late for coming to campus, and late collecting assignments. This is a form of time corruption, which results in consequences such as reduced grades, assignments not accepted, etc. http://www.kompasiana.com/98caca/5a9a2f0f16835f3ed27180e4/tren-koruptor-anak-muda-di-kalangan-pelajar

Not only among students, but many forms of corruption are also found in kindergarten or elementary school student nowadays. This action is a form of dishonesty of a child that sooner or later if not changed will become a bad habit. The forms of dishonesty such as lying to parents related to allowance, looking for answers to assignments/exams on the internet, skipping school on the grounds of illness, and much more. This phenomenon is a result of the lack of instilling honesty values in children. A lot of parents consider this as a small problem, even though something big usually starts small. Like corruption, acts of corruption exist because a person does not have and instill the value of honesty in himself, plus the person does not have insight or hold strong religious knowledge so that it is easily influenced.

From this phenomenon can be obtained data related to honesty among children and students as follows:

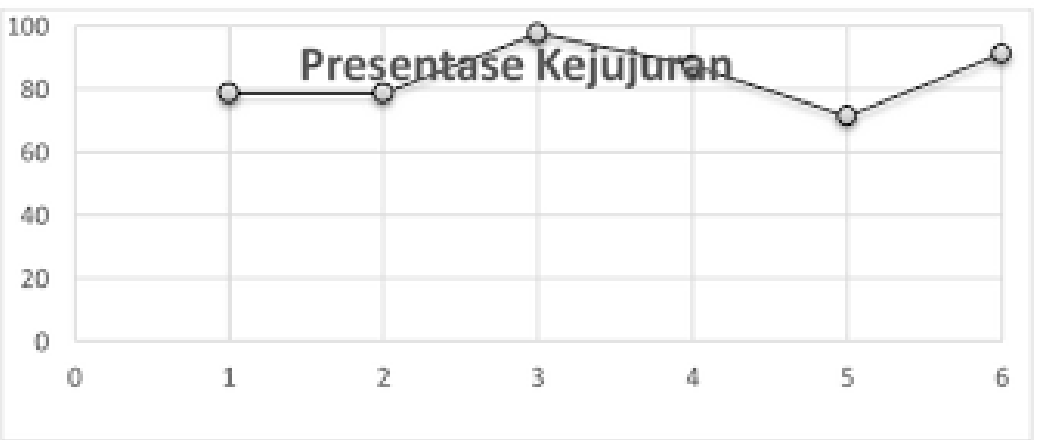

Figure 1.1 Graphic Act of Honesty Among Elementary School Children in 2017 Source : http://ejournal.upi.edu/index.php/mimbar 

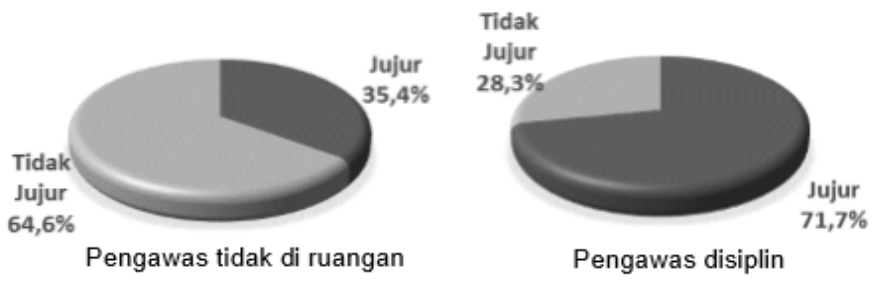

Figure 1.2 Student Behavior During Exam

Source: Faculty of Psychology, Muhammadiyah University, Surakarta

This phenomenon is also found in Jakarta, precisely in Joglo-West Jakarta. Many people there are still less concerned with the importance of instilling honesty values at an early age. These concerns can certainly be prevented from now on, namely by making various efforts such as the dissemination of honesty in early childhood; incorporate anti-corruption values in the education curriculum; instill the value of goodness in everyday life, and others. Law on the National Education System Number 20 Year 2003 Article 3 states that national education functions to develop and shape the character and civilization of a dignified nation in the context of developing the intellectual life of the nation. That is, the aim of national education leads to the development of various Indonesian characters.

Mulyasa (2013: 9) explains that through character education, students are expected to be able to independently improve and use their knowledge, study and internalize the values of character and noble character so that it is manifested in daily behavior. ${ }^{1}$ Megawangi (2004: 3-5) argues that a culture of corruption which is a practice of moral violations (dishonesty, irresponsibility, low discipline, low commitment to the values of goodness), is the main cause of the State's difficulty to rise from a critical state. ${ }^{2}$ The PERC (Political and Economic Risk Consultancy) survey results showed Indonesia's ranking in corruption scores was the highest in Asia in the 2006 period with a score of 8.16 (out of a total score of 10), then data from Transparency International (2002 and 2006), Indonesia was included in the 10 the most corrupt big in the world.

The importance of instilling honest character in children from an early age was also expressed by Schiller in Yaumi (2014: 65) that only with honesty can develop living conditions towards a better life, without honesty will have an impact on the setback of all efforts made. ${ }^{3}$ The government policy on character education is a challenge for the Corruption Eradication Commission (KPK) in providing services. Corruption Eradication Commission (KPK) is a state institution formed with the aim of increasing the results and effectiveness of efforts to eradicate corruption. As a government institution that plays an active role in combating corruption, the KPK has a high contribution. It is also this case that later encouraged the KPK to create an anti-corruption education program for young children.

This education is carried out by providing light information related to anti-corruption acts, such as: being honest; do good to people; diligent; and discipline. KPK has various of methods in the delivery of material and adjusted based on target. This time the KPK targets are children aged 7-9 years (grades 2-3 elementary school), for this reason the KPK chose to use the story telling method in the delivery of material. This tale can be used as a means of entertainment and instill the values of anti-corruption character. Story telling is a method that is considered the most effective, because the spread of moral messages can directly appeal to children. Indirectly, tale make children will not realize that they are being injected with anti-corruption values. This can also be done without the impression of force and pressure. Anti-corruption education using the story telling method is carried out by providing tales in which the understanding, attitudes, and behavior are related to anti-corruption acts. The character value that is featured in the tale is the importance of honesty, and not being greedy. The hope is that after the children know the importance of anti-corruption values (according to what is in the tales), they can implement anti-corruption measures in their daily lives.

Children education from an early age is a strategic step, because childhood is a golden period that will determine the future. Psychologically, children's stimulants respond more quickly or easily accept matter. Therefore children are often the target objects of the KPK, especially the kindergarten and elementary level.

The Al-Irshad Islamic Integrated Ibtidaiyah Madrasah is one of the unique schools, because this school instills a learning system with a relatively small number of students than primary schools in general. Each class

\footnotetext{
${ }^{1}$ H. E. Mulyasa. Manajemen Pendidikan Karakter. Jakarta: Bumi Aksara. 2013

${ }^{2}$ Ratna Megawati. Pendidikan Karakter: Solusi yang Tepat untuk Membangun Bangsa.. Jakarta: Indonesia Heritage Foundation. 2004

${ }^{3}$ Muhammad Yaumi. Pendidikan Karakter: Landasan, Pilar, dan Implementasi. Jakarta: Prenadamedia Group. 2014
} 
consists of 10-20 children. This school is a new school in the Joglo area, established in 2013. This school is located in DKI Complex Blok D. No.7-8 RT / RW 001/004 Joglo, Kembangan District - West Jakarta. 1164. Mr. Abdul as the Principal said that the application of this system was carried out so that children could focus more on learning, and teachers could better control of their students.

Being a "Child-Friendly City" is the ideals and hopes of all cities in Indonesia, one of which is Jakarta. Jakarta is one of the cities that has great concern for the development of a Child-Friendly Integrated Public Space (RPTRA). It has been noted that many RPTRAs have been built by the Provincial Government of DKI Jakarta in several areas, and can already be utilized by the surrounding community. West Jakarta itself has 20 RPTRAs scattered in five subdistricts, one of which is the Joglo RPTRA. The Joglo RPTRA is located in the DKI Joglo Complex, Block R, RT 12 RW 04, Joglo Sub-district, Kembangan District, West Jakarta, 11640.https://www.atmago.com/posts/rptra-ruang-publik-terpadu-ramah-anak-komplek-dki-joglopost id 351e434d-8725-4065-b247-ea883c86bc02

There are several problems occur around the RPTRA environment, one of which is the lack of understanding of anti-corruption values. Whereas the inculcation of anti-corruption values in early childhood is very important, because it is very helpful in shaping the character of children. The forms of anti-corruption that are easily applied to early childhood include being honest; discipline; and diligent. The inculcation of these values is part of efforts to prevent the spread of corruption. The expressions and writings "Dare to Be Honest, Great!" that we often find in the mass media and daily life, are expected to move the Indonesian people to have the courage to be honest both verbally, in actions and in deeds.

According to Hesty (25 years old) as a RPTRA officer who is also a local resident stated that since the establishment of the Joglo RPTRA, there have been many community activities held here, but for education related to anti-corruption education itself has never been held at all. This is because there are still many people (especially parents) who do not know the importance of instilling anti-corruption values from an early age, even some of them think that this is considered less important. Based on the problems faced by the partners, a socialization is needed to increase the knowledge of the local community regarding anti-corruption actions, their impact and benefits, so that they can change habits that have been embedded for a long time. Mellisa Fitri and Afita $^{4}$ conducted anti-corruption counseling activities for children in Babadan village, Selomirah, Ngablak, Magelang, Central Java.

According to Goslin in Ihrom (2004) socialization is a learning process experienced by a person to gain knowledge of skills, values, and norms so that he can participate as a member in his community group..$^{5}$ The inculcation of values, norms and skills tends to be more optimal if taught early on to children, rather than teaching when the child has started to grow up (junior-high school).

Unlike the case with kindergarten and elementary school children, the role of parents is very influential in children's behavior. Children at the age of 5-9 years tend to do activities in the main environment, namely the family, in the monitoring of parents or the closest people. From here a child begins to recognize the initial socialization process. Ihrom (2004) explained that socialization was divided into two stages, namely: (1) Primary Socialization, namely the first socialization carried out by individuals as a child. The primary socialization process shapes a child's personality into the general world and the family acts as an agent of socialization. (2) Secondary socialization is a process that introduces individuals into a new sector. The socialization process leads to the realization of an attitude of professionalism, and those who act as agents of socialization are educational institutions; employment agency; peer group; or the environment that larger than family.

According to Narmoko and Begong, the socialization process is relevant to personality formation. This can be divided into two, namely the process of socialization done (accidentally) through the process of social interaction, and the process of socialization which is done (intentionally) through the process of education and teaching. From Narmoko's statement it can be concluded, namely: (1) The socialization process should be carried out as soon as possible for kindergarten/elementary school children, because the inculcation of anticorruption values in kindergarten/elementary school children is seen as more effective. At this time children are very active and happy with new things that are usually applied in a game or a fairy tale/story. In addition, psychologically this age of children is more easily influenced (good things). (2) The process of socialization must be done often, not only once or twice. To form a strong personality, of course, need a lot of information, knowledge and insight that support. This can be obtained from socialization or outreach activities. ${ }^{6}$

The problem is that there are still many people who consider corruption is a normal thing in daily life. Possible solutions include: educating anti-corruption acts early on, instilling anti-corruption values in themselves, giving light sanctions to those who try to commit acts of corruption, such as: stealing; cheating; lying and others. This is done so that they feel deterrent and will not do it again. This effort is carried out so that

${ }^{4}$ Ardtiyani, Mellisa Fitri dan Afita Ratna Kholifah, Penyuluhan Anti KOrupsi Sejak Dini pada Anak-Anak Dusun Babadan, Selomirah, Ngablak, Magelang, Jawa Tengah, Jurnal Inovasi dan Kewirausahaan, Vol. 3 No. 2 , Mei 2014, h. 81-85

${ }^{5}$ Ihrom, Bunga Rampai. Sosiologi Keluarga. Jakarta: Yayasan Obor Indonesia. 2004

${ }^{6}$ Narmoko dan Bagong.Psikologi Teks Pengantar dan Terapan. Jakarta: Kencana. 2007. 
the younger generation will not commit acts of corruption when they later occupy strategic positions in an institution or hold important positions in a bureaucracy. Facts show highly educated people are vulnerable to the temptation of corruption because they usually occupy strategic positions in an institution or hold important positions bureaucracy.https://www.researchgate.net/publication/322789761_KEBIJAKAN PENDIDIKAN ANTI KORU PSI_DI_PERGURUAN_TINGGI [accessed Dec 18 2018].

This activity is one form of special event. According to Jim Macnamara (1996: xvi): "Special event is an event that is usually held to get the attention of clients, companies, or products". A special event is a situation that leads to the achievement of publicity through collaboration with the media in order to get certain satisfaction and help in marketing a product or service to the public. According to Goldblatt (2002), there are five stages that must be carried out to produce an effective and efficient special event, namely: (1) Research: a survey/observation of the place of activity and the target audience about two months before the event. This survey was conducted to determine the needs, desires, and expectations of the target audience. (2) Design: It takes extraordinary creativity from the implementation of special events. In this activity, the ability to speak; influence people; and entertaining is needed in the delivery of matter so that the target audience does not feel bored. The ability to create atmosphere; and games are also needed to attract the attention of the audience and create a deep impression for the audience. (3) Planning: At this stage frequent changes, additions, or reductions according to the availability of available resources. Activities undertaken such as: Forming team work and determining the duties of each member; Determine the matter idea and concept of the event being carried out; Budgeting; rundown; interviewees; consumption; and other equipment needed in activities; Determination of sponsorship; media partner; publication media; and others. (4) Coordinating: The chief executive must be able to coordinate the parties involved in this event so that they can work simultaneously with one goal in common, namely to produce a successful event. The forms of coordination include: Making sure all equipment is in place before the event begins; Ensuring the speakers and MCs are ready and arriving on time; Ensure all crew/members are ready in their respective positions; Run the event in accordance with the rundown that has been prepared previously. (5) Evaluation: A good evaluation will produce valuable data and facts, especially to support activities that will be carried out in the future. At this stage, report the results of activities and take responsibility for their work in written. In addition, preparing things such as: Review of the duties of each member; Review of activity implementation: were there any obstacles during the event or not? what was the good side of the event? what needs to be improved when carrying out similar activities/events in the future? how is the audience response/perception about the event being held? Finally, compiling the Activity Accountability Report (LPJ). This report is prepared together (team work) adjusted to the format that has been determined, and attach supporting documentation such as photos / videos.

\section{METHOD}

The technique used in the implementation of this event is socialization. The socialization carried out here is slightly different from the socialization in general, namely choosing informal socialization. According to Hanif (2013), informal socialization is a form of socialization that leads to family attitudes. In this socialization, individuals interact with each other in relationships that are to strengthen family ties, such as fellow group members, family, peers, and an association or community.

This informal socialization is more flexible and relaxed, so that it can create comfort among participants. The form of socialization applied was story telling about problems in everyday life.

According to Ganditama (2018) the pretest is a form of question, which the teacher posed to his student before starting a lesson. The question asked is the material that will be taught on that day (new material). Pretest is given with the intention of knowing whether there are among students who already know the lesson being taught. Pretest can be interpreted as an activity to test the level of student knowledge of the matter to be delivered and to know the students' initial abilities regarding the lessons being delivered.

Pretest is given before the story telling begins. Here are a few examples of questions asked to the children of The Al-Irshad Islamic Integrated Ibtidaiyah Madrasah, such as: What do you know about honesty? Mention the form of honesty at school? What is an example of honesty at home? When should we be honest?

Posttest is a form of question that is given after the lesson/material has been submitted (Ganditama, 2018). In short, the posttest is the final evaluation when the lesson taught on that day has been given. Posttests are given with the intention of whether students have understood and comprehend about the matter just given. The benefits of posttest to get a picture of the abilities achieved after the delivery of lessons. The results of this posttest will be compared with the results of the pretest that have been done, so it will be known how far the effect or influence of the teaching that has been done. Not only that, through this post-test can be known which parts of teaching material are still not understood by most students.

Posttest is done by asking questions to children of The Al-Irshad Islamic Integrated Ibtidaiyah Madrasah. For those who can answer correctly, given gifts in the form of snacks and stationery. As for the post-test questions about fairy tales that have been submitted, including: Kids, do you like the story? Could you tell who 
are the characters mentioned? How do you think about what Gori Gorilla has done to Momon Monkey? Good or bad? Can we break our promises like Gori Gorilla did? Why? What did Aida do when her father left her? What did Yosaku do in this story? Who cares about his friends? From the characters in the story, who is your favorite character? Why?

\section{RESULT AND DISCUSSION}

The stages of honesty socialization activities in the Joglo RPTRA include: First, the children are invited to get acquainted and sing together. Second, then given a pretest and brief information about honesty. Third, children are divided into four groups, each group consisting of 5-6 people. Each group will take turns to be taken to the room and listen to the story told by Bro $\mathrm{Zul}$ as the guest speaker. The story materials delivered to each group is different. Fourth, if one group is brought into the room to listen to a story, the other group waits outside the room while doing simple games to practice cooperation; their dexterity and honesty. Fifth, after all groups have got their turn to enter the room and get story material, invite them to answer questions. For those who succeed in answering the questions correctly, then we give prizes. Sixth, announcing the winners in the games that have been implemented.

The results of the "Socialization of Honesty in Early Childhood" pretest and posttest program are as follows: apparently there are still many children who do not understand the true meaning of honesty. This is clearly seen from the attitude of those who are silent and confused when given the question. But some of them actually already know the meaning of honesty narrowly, that is honesty means not to lie. Though the meaning of honesty itself is very broad.

After listening to the story delivered by Bro Zul, the children looked very happy. They were also very enthusiastic when answering questions raised by the commitee sisters. Many of them answer the questions correctly and get prizes. This shows that they can accept the story subjects well.

There are several indicators that determine the success or failure of an event, including: Targeted socialization events of around 25-30 people. Why a little? We chose a range of 25-30 participants so that storytelling activities could run more effectively, because the target audience were children. More and more children in a group will certainly be more crowded, and this is feared not conducive.

The story materials conveyed is based on from daily life which is closely related to them. This is done to make it easier for children to absorb/capture the contents of the story. The language and method of delivering the material is done lightly, relaxed, and full of expression.

Based on the results of the posttest conducted, it was concluded that the children of The Al-Irshad Islamic Integrated Ibtidaiyah Madrasah were very satisfied with the material presented. Evidently they were able to capture the material presented, and answer the questions raised by the committee's sister about the fairy tale. Not only that, we can see the satisfaction of the participants from their enthusiasm when listening to fairy tales. They are calm when fairy tales are red, and active when told to ask questions.

Furthermore, evaluating the strengths and weaknesses of this event, such as: (1) Strengths: Submission of topics is very effective, namely by giving storytelling using props, so that children follow and listen very enthusiastically; Provide topics or content that is light and delivered with two-way communication, so that children do not get bored following the event; Games that are held can increase collaboration; honesty; and dexterity in each child. (2) Weaknesses: slight difficulty in managing very active children; less able to coordinate children in listening to the tales conveyed; and Event rhythm settings.

\section{CONCLUSION}

Honesty is very important to be applied in everyday life. The impact of dishonesty will usually make someone lose the reputation that was achieved. The rise of this case is one of caused by the lack of human concern for the values of honesty, which must be applied in each individual.

Everything that is good must of course be rushed, including instilling the values of honesty early on in children. If they are used to being honest from childhood, that personality will be carried by them until they become adults. Of course, honesty instilled early on in children can encourage them to do even better, so as to create a young generation of quality, excellence, and dignity.

Suggestions that can be given when delivering material is to provide fairy tale material in the form of books so that children can take it home and read, so they will always remember it.

\section{REFERENCES}

Ahmadi, 1991. Psikologi Sosial. Jakarta : PT. Rineka Cipta

Fitri, Ardtiyani Mellisa. Jurnal Inovasi dan Kewirausahaan. 2014 (No.2,Volume 3). Yogyakarta: Universitas Islam Indonesia 
Firda, Nabilah. (2011, Juli 23). Faktor Penyebab Korupsi Menggila di Indonesia. Retived Oktober 3, 2018, from Kompasiana.com : www.kompasiana.com

Ganditama. Pengertian Pretest dan Posttest. 2018. Jakarta

Kadir, Yusrianto. (2018, Januari). Kebijakan Pendidikan Anti Korupsi di Perguruan Tinggi. Retived Desember 18, 2018. Sulawes: Universitas Gorontalo

Kamus Besar Bahasa Indonesia (KBBI). Pengertian Sosialisasi. Retived Oktover 20, 2018 from KBBI Online: https://kbbi.web.id/sosialisasi

Kurniawan,Iqbal. 9\(2016, Oktober 17). RPTRA (Ruang Publik Terpadu Ramah Anak) Komplek DKI Joglo. Retived Oktober 5, 2018, from Atma GO: www.atmago.com

Megawangi, Ratna. 2004. Pendidikan Karakter: Solusi yang Tepat untuk Membangun Bangsa. Jakarta: Indonesia Heritage Foundation.

Mulyasa, H. E. 2013. Manajemen Pendidikan Karakter. Jakarta: Bumi Aksara.

Salsabila. (2018, Maret 3). Tren Koruptor anak Muda di Kalangan Pelajar. . Retived Oktober 3, 2018, from Kompasiana.com : www.kompasiana.com

Undang-undang No. 20 Tahun 2003 Tentang Sistem Pendidikan Nasional.

Yaumi, Muhammad. 2014. Pendidikan Karakter: Landasan, Pilar, dan Implementasi. Jakarta: Prenadamedia Group.

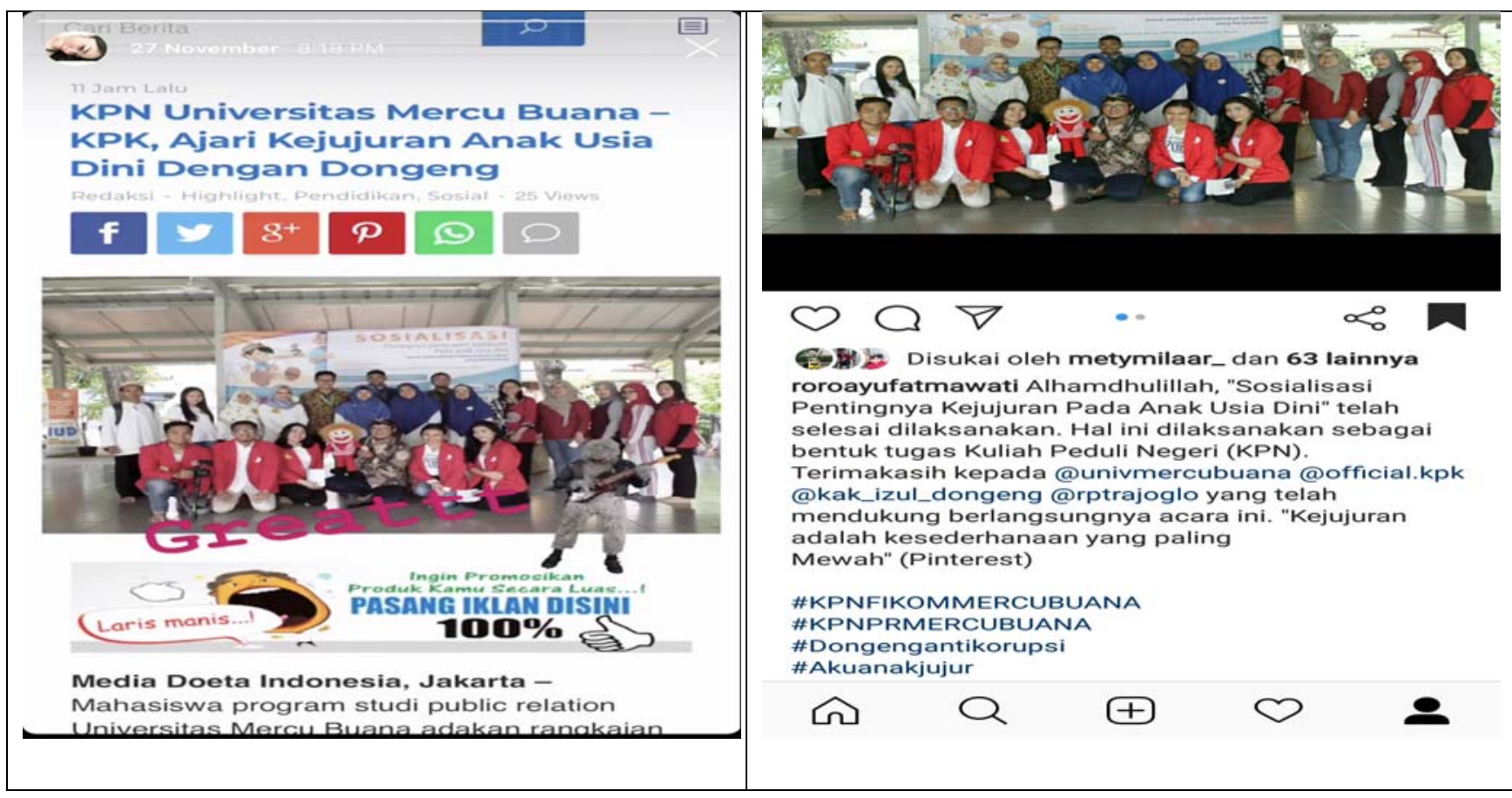

Figure 2. Implimentation of Activities 